\title{
The Association of ${ }^{14} \mathrm{G}$-Labelled Vitamin $\mathrm{D}_{2}$ with Rat Serum Proteins
}

\author{
BY KAREEN J. INNES CHALK AND E. KODICEK \\ Dunn Nutritional Laboratory, University of Cambridge and Medical Research Council
}

(Received 13 October 1960)

Separation of serum by electrophoresis has shown that certain lipids, found in blood, have the same electrophoretic mobilities as some of the proteins. It is believed that this is due to the attachment of the lipids to the serum proteins in transport by the blood stream. Vitamin A alcohol was found to be carried by $\alpha_{1}$-globulin (Garbers, Gillman \& Peisach, 1958, 1960); carotene was located mainly with $\beta$-globulin, but also with albumin and the $\alpha$-globulins in human serum (Crook \& El-Marsafy, 1954) and with albumin in bovine serum (Erwin, Varnell \& Page, 1959); corticosteroids appeared to be associated with albumin (Daughady, 1956, 1958). The transport of vitamin D by human serum has been studied (Morgan, Thomas, Haddock \& Howard, 1958; Thomas et al. 1959). These authors separated, by electrophoresis on starch, the serum proteins from patients given high doses of vitamin $\mathrm{D}$, and tested the protein fractions for antirachitic activity. Owing to the low level of the vitamin in blood they had not enough material to subdivide the protein fractions, but they were able to show that it can all be found in the albumin and $\alpha$-globulin regions. Similar results were obtained from human serum incubated in vitro with vitamin $\mathbf{D}$.

By using ${ }^{14} \mathrm{C}$-labelled vitamin $\mathrm{D}_{2}$ it has been possible to analyse smaller regions of the starch block after electrophoresis and to study thereby the distribution of the vitamin with respect to protein in more detail. The serum used in these experiments was obtained from rats and incubated in vitro with ${ }^{14} \mathrm{C}$-labelled vitamin $\mathrm{D}_{2}$. For preliminary communication, see Chalk \& Kodicek (1960).

\section{MATERIALS}

Serum. About $45 \mathrm{ml}$. of unhaemolysed blood was obtained by heart puncture from 6-month-old, male, stock rats. After an hour at room temperature the blood was centrifuged and the serum used on the same day.

Vitamin $D_{2}$. Uniformly ${ }^{14} \mathrm{C}$-labelled vitamin $D_{2}$ (specific activity, $0.4 \mu \mathrm{c} / \mathrm{mg}$.), prepared by Kodicek (1955), was dissolved in propylene glycol $(0.5 \mathrm{mg} . / \mathrm{ml}$.).

Buffer. Barbiturate buffer, pH 8.6, was used for electrophoresis: $10.3 \mathrm{~g}$. of sodium diethylbarbiturate and $1.84 \mathrm{~g}$. of diethylbarbituric acid (British Drug Houses Ltd.) per litre.

Starch. Potato starch (British Drug Houses Ltd.) was
Soxhlet-extracted for $6 \mathrm{hr}$. with diethyl ether to decrease its fat content, which would otherwise have contaminated the lipids extracted after electrophoresis.

Organic solvents. A.R.-grade diethyl ether, propan-1-ol and light petroleum (b.p. 40-60 ${ }^{\circ}$ ) were purified by distillation. The other organic solvents used were A.R.-grade methanol, acetone (British Drug Houses Ltd.) and absolute ethanol (The Distillers Co. Ltd.).

Folin-Ciocalteu reagent. The Folin-Ciocalteu reagent for tyrosine (British Drug Houses Ltd.) was kept in a dark bottle in the refrigerator and used within 2 months of preparation.

\section{METHODS}

\section{Incubation of serum with vitamin $D_{2}$}

For each experiment $20 \mu$ l. of ${ }^{14} \mathrm{C}$-labelled vitamin $\mathrm{D}_{2}$ $(10 \mu \mathrm{g}$.) in propylene glycol was added slowly, with shaking, to $4 \mathrm{ml}$. of serum. The serum was incubated at $37^{\circ}$ for $30 \mathrm{~min}$. and then separated by electrophoresis on starch.

\section{Electrophoresis on starch}

The method used was a modification of that devised by Kunkel \& Slater $(1952 a)$. Starch $(150 \mathrm{~g}$.) was mixed to a stiff paste with barbiturate buffer and poured into a rectangular metal mould $(21 \mathrm{~cm} . \times 8 \mathrm{~cm} . \times 1.5 \mathrm{~cm}$. $)$ lined with filter paper. After drying for $2-3 \mathrm{hr}$. at room temperature, the block was turned out on a glass plate and the paper removed. The serum, after incubation with vitamin $\mathrm{D}_{2}$, was added to the block by mixing it with dry starch and pouring it into a $1 \mathrm{~cm}$. wide trough in the block, $4.5 \mathrm{~cm}$. from the cathode end. At each side of the trough $0.5 \mathrm{~cm}$. margins were left free from serum to reduce streaking at the edges. A small bromophenol-blue marker was put in the middle of the trough containing the serum sample, to follow the progress of electrophoresis. Finally the block was covered with a second glass plate. It was equilibrated in a Shandon electrophoresis tank at $7^{\circ}$ for $3 \mathrm{hr}$. in a refrigerator and then run at $400 \mathrm{v}$ and $32 \mathrm{~mA}$ for $11 \mathrm{hr}$. During the run the temperature increased only by $5^{\circ}$.

\section{Analyses of the block}

Two different procedures were used in the segmenting of the starch block for analysis. The blocks were cut, at right angles to their lengths, into $1 \mathrm{~cm}$. segments. In Expt. 1, each segment was cut into three pieces of 3,1 and $3 \mathrm{~cm}$. widths, and dried over $\mathrm{P}_{2} \mathrm{O}_{5}$. The $0.5 \mathrm{~cm}$. margins on each side were discarded. The two $3 \mathrm{~cm}$. pieces were used for vitamin D analysis; two different extraction procedures were used as described below. The $1 \mathrm{~cm}$. pieces were used for protein analysis; they were extracted with $3 \mathrm{ml}$. of saline $(0.9 \% \mathrm{NaCl}$ soln.) and centrifuged, and $2 \mathrm{ml}$. was taken for the estimation of protein.

Bioch. 1961, 79 
In Expt. 2, the set of $1 \mathrm{~cm}$. segments was not further subdivided, but each whole segment was extracted successively by the three procedures described below. Each segment was dried over $\mathrm{P}_{2} \mathrm{O}_{5}$ and shaken with $12 \mathrm{ml}$. of $0.9 \% \mathrm{NaCl}$ soln. and centrifuged. A sample (1 ml.) of the supernatant was taken for protein analysis and $5 \mathrm{ml}$. for measurement of saline-extractable ${ }^{14} \mathrm{C}$-labelled material. The remainder, containing the starch, was extracted with light petroleum. Finally it was re-extracted with ethanoldiethyl ether $(3: 1, v / v)$, after being boiled with methanol as described below. Each of the fractions was analysed for vitamin $\mathrm{D}$ by measurements of radioactivity, paper chromatography and biological assay.

Protein analysis. The samples of the $\mathrm{NaCl}$ extracts reserved for protein analysis were assayed for protein by the method of Peters \& van Slyke (1932). Each sample (equivalent to one-twelfth of each segment) was added to $25 \mathrm{ml}$. of water, followed by $2 \mathrm{ml}$. of $5 \mathrm{~N}-\mathrm{NaOH}$ and $3 \mathrm{ml}$. of Folin-Ciocalteu reagent, and the solution was made up to $50 \mathrm{ml}$. After 5-10 min. the absorption of the solution was measured photometrically with a Wratten filter no. 70. A calibration curve was made with bovine serum albumin (Armour Laboratories Ltd.) in concentrations of up to $5 \mathrm{mg} . / \mathrm{ml}$. A serum albumin standard was included in each set of determinations and was found to agree with the calibration curve.

\section{Extraction of vitamin $D$}

(a) Saline extraction. In Expt. 1, one of the $3 \mathrm{~cm}$.-wide pieces of each segment was shaken with $6 \mathrm{ml}$. of $0.9 \% \mathrm{NaCl}$ soln. and centrifuged, and a $3 \mathrm{ml}$. sample of the supernatant taken. This was heated with $3 \mathrm{ml}$. of methanol for 3 min. with a cold finger condenser and extracted three times with $5 \mathrm{ml}$. portions of light petroleum. The extracts were combined and evaporated to dryness under reduced pressure. In Expt. 2, $5 \mathrm{ml}$. samples of the supernatant mixed with $5 \mathrm{ml}$. of ethanol were extracted in the same way.

(b) Extraction with light petroleum. In Expt. 1, the other $3 \mathrm{~cm}$.-wide piece of each segment was suspended in $3 \mathrm{ml}$. of ethanol and extracted three times with $5 \mathrm{ml}$. of light petroleum. In Expt. 2, the remaining $6 \mathrm{ml}$. of $\mathrm{NaCl}$ extract containing starch was extracted three times with $5 \mathrm{ml}$. of light petroleum. The combined extracts in each experiment were evaporated to dryness under reduced pressure.

(c) Boiling with methanol, followed by ethanol-diethyl ether extraction. This method of extraction was used only on the segments from Expt. 2. Each segment was refluxed with $80 \mathrm{ml}$. of methanol for $2 \mathrm{hr}$. to facilitate the subse. quent extraction with ethanol-diethyl ether. The meth. anol was removed by evaporation under reduced pressure, and the starchy material dried over $\mathrm{P}_{2} \mathrm{O}_{5}$ and Soxhletextracted for $5 \mathrm{hr}$. with ethanol-diethyl ether $(3: 1, \nabla / v)$. The extract was evaporated to dryness under reduced pressure.

\section{Estimation of vitamin $D$}

(a) Radioactivity measurements. All the various fractions from all the segments in both experiments were counted with a thin end-window Geiger-Müller tube. They were dissolved in $0.1 \mathrm{ml}$. of ethanol and $0.05 \mathrm{ml}$. of each was put on a planchet. The results were corrected for selfabsorption and expressed in $\mu \mathrm{mo}$. After being counted, the plated samples were transferred with diethyl ether to the residual solutions and evaporated to dryness.

(b) Reversed-phase paper chromatography, by the method of Kodicek \& Ashby (1954). In Expt. 1, the fractions obtained from each experiment were redissolved in $0.1 \mathrm{ml}$. of ethanol; $0.05 \mathrm{ml}$. of each was streaked on a $2.5 \mathrm{~cm}$.-wide strip of paraffin-impregnated, Whatman no. 2 paper. A $10 \mu$ g. spot of unlabelled vitamin $D_{2}$ was applied to each strip as a marker. The strips were developed by ascending chromatography in methanol-propan-1-ol-water (16:3:1, by vol.). The position of the vitamin $D_{2}$ was located by the absorption of the marker when viewed with a Hanovia short-wave $(256 \mathrm{~m} \mu)$ ultraviolet lamp. Radioautographs were made by leaving the strips in contact with Kodirex X-ray film for 3 weeks. Those strips which gave positive radioautographs were counted with a thin endwindow Geiger-Müller tube.

In Expt. 2, the saline, as well as the light-petroleum extracts of the segments, were combined in such a way as to correspond to the three radioactive peaks separated by electrophoresis, namely the peaks at the point of application, at the $\alpha_{2}$-globulin and at the albumin. These fractions were split into two portions: $40 \%$ for radioautography as described above, and $60 \%$ for biological assay.

(c) Biological assay. The vitamin $\mathrm{D}$ activity present in the various extracts was assayed by using the method of Bourdillon, Bruce, Fischmann \& Webster (1931). The rachitic rats given the test doses were $X$-rayed 2 weeks later, and the healing was compared with that obtained in rats dosed with 40,20 and 10 i.u. of vitamin $D_{2}$. The extracts from Expt. 1 were combined into the $\alpha_{2}$-globulin and albumin peaks, as described above for Expt. 2. As no radioactive material was found at the origin, this region was not assayed for vitamin $D$ activity. In view of the small amount of vitamin $D$ present, only a one-point assay was possible, with two to five rats. The doses were fed on squares of rice-paper.

\section{RESULTS}

\section{Protein analysis after starch electrophoresis}

Four clear peaks were found: a fast-moving, large albumin fraction, with the $\alpha_{1}$-globulin appearing as a shoulder, followed by small $\alpha_{2}-, \beta$ and $\gamma$-globulin peaks (Figs. 1, 2). The albumin peak moved further in Expt. 1 than in Expt. 2, giving a better separation.

\section{Distribution of radioactive material after electrophoresis}

Expt. 1. Two radioactive peaks were found in the distribution of both the saline and light-petroleum extracts. One corresponded with $\alpha_{2}$-globulin and the other with albumin (Fig. 1). Table 1 shows the quantitative distribution of radioactive material between the two proteins. It differed in the two methods of extraction. Light petroleum extracted $17.5 \%$ of the radioactive material from the $\alpha_{2}$ globulin and $30.5 \%$ from the albumin fraction; saline extracted $10.5 \%$ from $\alpha_{2}$-globulin and $10.1 \%$ from albumin. Hence light petroleum extracted 
Table 1. Relationship between extracted ${ }^{14} \mathrm{C}$-labelled material and the $\alpha_{2}$-globulin and albumin fractions (Expt. 1)

\begin{tabular}{|c|c|c|c|c|c|}
\hline & \multicolumn{2}{|c|}{ Recovery of added ${ }^{14} \mathrm{C}(\%)$} & \multirow[b]{2}{*}{$\begin{array}{l}\text { Protein } \\
\quad(C)\end{array}$} & \multicolumn{2}{|c|}{$\begin{array}{l}{ }^{14} \mathrm{C} \text {-Labelled material } \\
\text { per unit protein }\end{array}$} \\
\hline & $\begin{array}{l}\text { In saline } \\
\quad(A)\end{array}$ & $\begin{array}{c}\text { In light } \\
\text { petroleum } \\
(B)\end{array}$ & & $\begin{array}{l}\text { In saline } \\
(A / C)\end{array}$ & $\begin{array}{c}\text { In light } \\
\text { petroleum } \\
(B / C)\end{array}$ \\
\hline $\begin{array}{l}\alpha_{2}-\text { Globulin fraction } \\
\text { Albumin fraction }\end{array}$ & $\begin{array}{l}10 \cdot 5 \\
10 \cdot 1\end{array}$ & $\begin{array}{l}17 \cdot 5 \\
30 \cdot 5\end{array}$ & $\begin{array}{l}17 \\
57\end{array}$ & $\begin{array}{l}0.62 \\
0 \cdot 18\end{array}$ & $\begin{array}{l}1.03 \\
0.54\end{array}$ \\
\hline Total & $20 \cdot 6$ & $48 \cdot 0$ & - & - & - \\
\hline
\end{tabular}

Table 2. Relationship between extracted ${ }^{14} \mathrm{C}$-labelled material and the protein fractions (Expt. 2)

\begin{tabular}{|c|c|c|c|c|c|c|c|}
\hline & \multicolumn{3}{|c|}{ Recovery of added ${ }^{14} \mathrm{C}(\%)$} & \multicolumn{4}{|c|}{${ }^{14} \mathrm{C}$-Labelled material per unit protein } \\
\hline & $\begin{array}{c}\text { In saline } \\
(A)\end{array}$ & $\begin{array}{l}\text { In light } \\
\text { petroleum } \\
(B)\end{array}$ & $\begin{array}{l}\text { In ethanol- } \\
\text { diethyl } \\
\text { ether } \\
(C)\end{array}$ & $\begin{array}{l}\text { Protein } \\
(\%) \\
(D)\end{array}$ & $\begin{array}{c}\text { In saline } \\
(A / D)\end{array}$ & $\begin{array}{c}\text { In light } \\
\text { petroleum } \\
(B \mid D)\end{array}$ & $\begin{array}{c}\text { In ethanol- } \\
\text { diethyl } \\
\text { ether } \\
(C / D)\end{array}$ \\
\hline $\begin{array}{l}\alpha_{\mathrm{a}}-\text { Globulin fraction } \\
\text { Albumin fraction } \\
\text { Origin }\end{array}$ & $\begin{array}{r}24 \cdot 5 \\
14 \cdot 2 \\
9 \cdot 9\end{array}$ & $\begin{array}{l}28 \cdot 5 \\
21 \cdot 1 \\
13 \cdot 1\end{array}$ & $\begin{array}{l}39 \cdot 2 \\
33 \cdot 9 \\
18 \cdot 2\end{array}$ & $\begin{array}{r}19 \\
61 \\
0\end{array}$ & $\begin{array}{c}1.29 \\
0.23 \\
-\end{array}$ & $\begin{array}{c}1.50 \\
0.35 \\
-\end{array}$ & $\begin{array}{c}2.06 \\
0.56 \\
-\end{array}$ \\
\hline Total & $48 \cdot 6$ & $62 \cdot 7$ & $91 \cdot 3$ & & & & \\
\hline
\end{tabular}
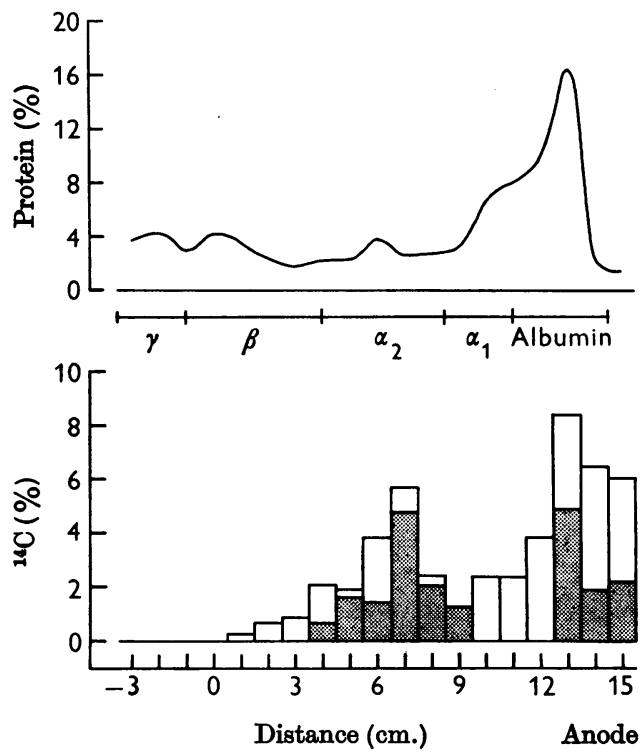

Fig. 1. Distribution of ${ }^{14} \mathrm{C}$ after electrophoresis of rat

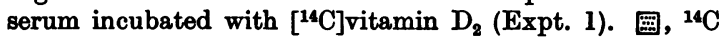
extractable with saline; $\square$, excess of ${ }^{14} \mathrm{C}$ extractable with light petroleum; $\alpha_{1}, \alpha_{2}, \beta$ and $\gamma$ refer to the respective globulins.

$48.0 \%$, and saline extracted $20.6 \%$, of the added radioactive material.

The ${ }^{14} \mathrm{C}$-labelled material per unit protein was calculated from the ratio of recovered ${ }^{14} \mathrm{C}$ to the amount of protein. In the light-petroleum extracts, the $\alpha_{2}$-globulin fraction showed a higher ratio $(1.03)$ than the albumin fraction $(0.54)$, although the albumin carried more total radioactive
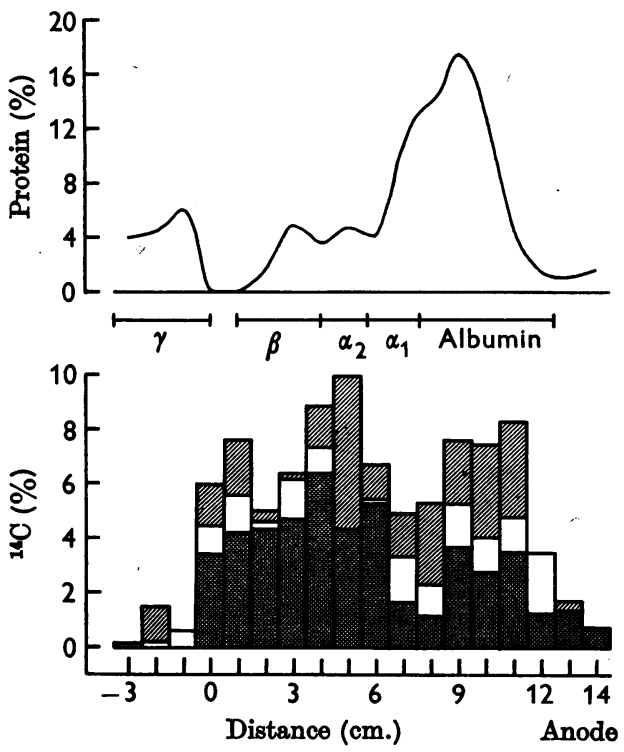

Fig. 2. Distribution of ${ }^{14} \mathrm{C}$ after electrophoresis of rat serum incubated with $\left[{ }^{14} \mathrm{C}\right]$ vitamin $\mathrm{D}_{2}$ (Expt. 2). 圈, ${ }^{14} \mathrm{C}$ extractable with saline; $\square$, excess of ${ }^{24} \mathrm{C}$ extractable with light petroleum; $叉$, residual ${ }^{14} \mathrm{C}$ extractable, after boiling with methanol, with ethanol-diethyl ether; $\alpha_{1}, \alpha_{2}, \beta$ and $\gamma$ refer to the respective globulins.

material. In the saline extracts, again, the corresponding ratios to protein were greater in the $\alpha_{2}$-globulin (0.62) than in the albumin fraction $(0 \cdot 18)$.

Expt. 2. A study was made of the distribution of radioactive material extractable by saline followed by light petroleum, and then by more drastic 
extraction techniques. All three procedures showed the two ${ }^{14} \mathrm{C}$-labelled peaks observed in Expt. 1 and in addition a third peak at the point of application (Fig. 2). In Table 2, the first three columns show the calculated percentage of radioactive material extractable by each procedure. Since the different extractions were performed successively, and only a portion of the saline extract was used for analysis of ${ }^{14} \mathrm{C}$, correction was made for this procedure. It was shown (see Recovery of radioactive material) that light petroleum extracted the portion also extractable by saline; the ethanol-diethyl ether procedure extracted all or almost all the ${ }^{14} \mathrm{C}$ labelled material. The data quoted for the ethanoldiethyl ether procedure therefore includes the material extracted by light petroleum, and that given for the light-petroleum extraction includes the material removed by saline.

Saline thus extracted $48.6 \%$, light petroleum $62.7 \%$ and ethanol-diethyl ether (after boiling with methanol) $91.3 \%$. The recoveries were greater than in Expt. 1, particularly because of the amount found in the $\alpha_{2}$-globulin fraction. The total radioactive material as obtained by ethanol-diethyl ether extraction was $39.2 \%$ from the $\alpha_{2}$-globulin, $33.9 \%$ for the albumin fraction and $18.2 \%$ from the origin. As in Expt. 1, the ${ }^{14} \mathrm{C}$-labelled material per unit protein was several times greater in the $\alpha_{2}$-globulin fraction than in the albumin, irrespective of the method of extraction.

\section{Recovery of radioactive material}

Preliminary experiments to test the extraction procedures were done by measuring the total radioactive material recoverable direct from serum or from serum mixed with starch without recourse to electrophoresis. For each determination $1 \mathrm{ml}$. of serum containing $2.5 \mu \mathrm{g}$. of ${ }^{14} \mathrm{C}$-labelled vitamin $\mathrm{D}_{2}$ was used. The different extraction procedures used to recover vitamin $D$ were investigated : extraction with saline (procedure 1), light petroleum (pro- cedure 2) and ethanol-diethyl ether after refluxing with methanol (procedure 3). Extracts were made of ${ }^{14} \mathrm{C}$-labelled vitamin $\mathrm{D}_{2}$ incubated with serum, of the same left overnight on a $5 \mathrm{~g}$. starch block at $7^{\circ}$, and of ${ }^{14} \mathrm{C}$-labelled vitamin $\mathrm{D}_{2}$ in propylene glycol or ethanol, without serum, left on a starch block overnight.

The recoveries are shown in Table 3. Light petroleum extracted 86 and $91 \%$ of the radioactive material from starch in the absence of serum. In the presence of serum the percentage extractable was reduced to $50 \%$. Saline extracted 46 and $37 \%$ of the radioactive material in the absence of serum, and $25 \%$ in the presence of serum. On refluxing with methanol, followed by extraction with ethanol-diethyl ether, a recovery of $95 \%$ of the radioactive material was obtained even in the presence of serum.

\section{Identity of radioactive material with vitamin $D$}

Both biological assay and reversed-phase paper chromatography showed that only a fraction of the radioactive material recovered was vitamin $D$ (Table 4).

The reversed-phase paper chromatography permitted the quantitative determination of the radioactive material from the control experiments, mentioned above, whereas the ${ }^{14} \mathrm{C}$ counts on paper chromatograms for the Expts. 1 and 2 only allowed a qualitative picture (Fig. 3). Biological results were obtained for the various fractions in Expts. 1 and 2 as shown in Table 4.

After incubation of vitamin D with serum, only $27 \%$ of the radioactive material recoverable with light petroleum was still the vitamin. The same results were obtained after leaving the incubated vitamin $\mathrm{D}$ on starch overnight. The recoveries of vitamin $\mathrm{D}$ in the radioactive material that was obtained from the origin, $\alpha_{2}$-globulin and albumin fractions by saline or by light-petroleum extraction, ranged from 10 to $38 \%$.

Table 3. Recovery of ${ }^{14} \mathrm{C}$-labelled material

1. Saline extract of Sample
${ }^{14} \mathrm{C}$-Labelled vitamin $\mathrm{D}_{2}$ incubated with serum, left on starch overnight ${ }^{14} \mathrm{C}$-Labelled vitamin $\mathrm{D}_{2}$ in propylene glycol left on starch overnight ${ }^{14} \mathrm{C}$-Labelled vitamin $\mathrm{D}_{2}$ in ethanol left on starch overnight

2. Light-petroleum extract of ${ }^{14} \mathrm{C}$-Labelled vitamin $\mathrm{D}_{2}$ incubated with serum ${ }^{14}$ C-Labelled vitamin $\mathrm{D}_{2}$ incubated with serum, left on starch overnight ${ }^{14} \mathrm{C}$-Labelled vitamin $\mathrm{D}_{2}$ in propylene glycol left on starch overnight ${ }^{14} \mathrm{C}$-Labelled vitamin $\mathrm{D}_{2}$ in ethanol left on starch overnight

3. Ethanol-diethyl ether extract, after methanol treatment ${ }^{14} \mathrm{C}$-Labelled vitamin $\mathrm{D}_{2}$ incubated with serum, left on starch overnight ${ }^{14} \mathrm{C}$-Labelled vitamin $\mathrm{D}_{2}$ in propylene glycol left on starch overnight

\begin{tabular}{|c|}
\hline $\begin{array}{c}\text { Recovery } \\
\text { of added } \\
{ }^{14} \text { C-labelled } \\
\text { material } \\
(\%)\end{array}$ \\
\hline $\begin{array}{l}25 \\
46 \\
37\end{array}$ \\
\hline $\begin{array}{l}50 \\
50 \\
86 \\
91\end{array}$ \\
\hline
\end{tabular}


Table 4. Identity of radioactive material with vitamin $D$

Vitamin D

\begin{tabular}{|c|c|c|c|}
\hline $\begin{array}{c}\text { From } \\
{ }_{14} \mathrm{C} \text { count } \\
\text { of sample } \\
(\mu \mathrm{g} .)\end{array}$ & By b & $\frac{\text { l assay }}{\begin{array}{c}(\% \text { of } \\
\text { radioactive } \\
\text { material })\end{array}}$ & $\begin{array}{c}\text { By paper } \\
\text { chromatography* } \\
\text { (\% of } \\
\text { radioactive } \\
\text { material) }\end{array}$ \\
\hline $\begin{array}{l}5 \cdot 0 \\
5 \cdot 0\end{array}$ & - & 二 & $\begin{array}{l}27 \\
28\end{array}$ \\
\hline $\begin{array}{l}1.05 \\
1.00\end{array}$ & $\begin{array}{l}0 \cdot 10 \\
0 \cdot 25\end{array}$ & $\begin{array}{l}10 \\
25\end{array}$ & - \\
\hline $\begin{array}{l}0.65 \\
2.05\end{array}$ & $\begin{array}{l}0 \cdot 16 \\
0 \cdot 26\end{array}$ & $\begin{array}{l}25 \\
13\end{array}$ & - \\
\hline $\begin{array}{l}1.2 \\
0.7 \\
0.5\end{array}$ & $\begin{array}{l}0.25 \\
0.17 \\
0.15\end{array}$ & $\begin{array}{l}21 \\
24 \\
29\end{array}$ & E \\
\hline $\begin{array}{l}1 \cdot 6 \\
1.4 \\
0 \cdot 8\end{array}$ & $\begin{array}{l}0.46 \\
0.58 \\
0.28\end{array}$ & $\begin{array}{l}29 \\
38 \\
35\end{array}$ & $=$ \\
\hline
\end{tabular}

Control experiments

Light-petroleum extract of

${ }^{14}$ C-Labelled vitamin $\mathrm{D}_{2}+$ serum

${ }^{14} \mathrm{C}$-Labelled vitamin $\mathrm{D}_{2}+$ serum on starch

Expt. 1

Saline extract of

$\alpha_{2}$-Globulin fraction

Albumin fraction

Light-petroleum extract of $\alpha_{2}$-Globulin fraction

Albumin fraction

Expt. 2

Saline extract of

$\alpha_{2}$-Globulin fraction

Albumin fraction

Origin

Light-petroleum extract of $\alpha_{2}$-Globulin fraction

Albumin fraction

Origin

* The percentage count was obtained by calculating the ratio of radioactivity of the vitamin $D$ spot to that of the whole paper strip.

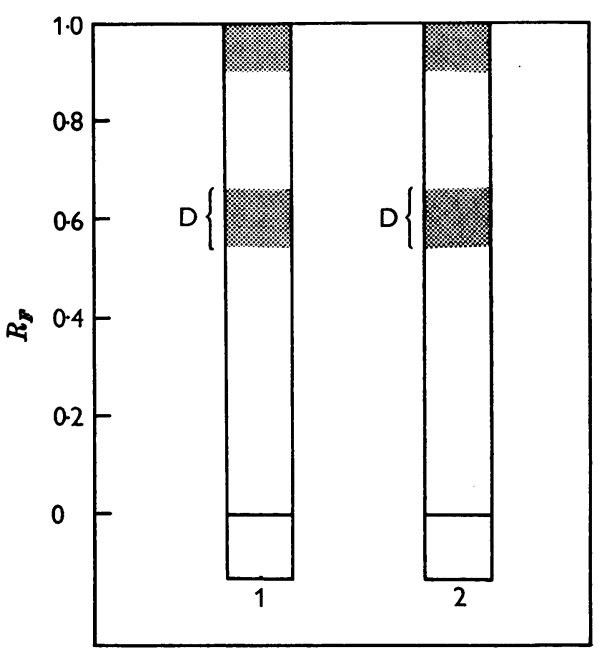

Fig. 3. Radioautographs of reversed-phase paper chromatograms of light-petroleum extracts. 1, Extract of ${ }^{14} \mathrm{C}$-labelled vitamin $\mathrm{D}_{2}$ incubated with serum, left on starch; 2, extract of a $1 \mathrm{~cm}$. segment from Expt. 1 (13 cm. from the point of application); $D$, area corresponding to that occupied by the unlabelled vitamin $D$ marker.

\section{DISCUSSION}

In the absence of serum, vitamin $D$ did not move from the origin, as shown by radioautography of papers after electrophoresis of the pure vitamin.
After incubation with rat serum, vitamin D acquired electrophoretic mobility, suggesting an interaction between serum and vitamin $D$. The proteins involved were $\alpha_{2}$-globulin and albumin. Although the separation of $\alpha_{1}$-globulin from albumin was not good, the position of the vitamin D seemed to correspond with the albumin peak. In Expt. 2 the third peak at the origin, consisting of about one-fifth of the ${ }^{14} \mathrm{C}$-labelled material, might be excess of vitamin $D$, owing to the high levels used in these experiments. Previously, with ten times the concentration of vitamin $D$, almost all was found at the origin.

The distribution of radioactive material between the two proteins was approximately equal, the albumin carrying a little more in the first experiment and the $\alpha_{2}$-globulin in the second. Owing to the high concentration of albumin in serum, the capacity of $\alpha_{2}$-globulin for vitamin $D$, in terms of radioactive material per unit protein, was about two to four times as great as that of albumin. The distribution of vitamin $D$ in rat serum confirms the results obtained by the Baltimore workers (Morgan et al. 1958; Thomas et al. 1959) with human serum, in which they used unlabelled vitamin and assayed it biologically. The use of ${ }^{14} \mathrm{C}$-labelled vitamin $\mathrm{D}$ and the modified technique made it possible to obtain the vitamin content at $1 \mathrm{~cm}$. intervals without pooling the samples. The greater resolution obtained by this method gave two separate 
fractions of vitamin $D$, thereby showing an association with both $\alpha_{2}$-globulin and albumin. Using the difference in extractability by light petroleum and ethanol-diethyl ether of the free and protein-bound vitamin D, Kodicek, Cruickshank \& Ashby (1960) confirmed that the main portion of ${ }^{14} \mathrm{C}$-labelled vitamin $\mathrm{D}_{2}$ in the blood of rats injected intracardially with the vitamin is bound to protein.

It thus appears that vitamin $D$ reaching the blood stream, either from the intestinal lumen or direct, is transported by the plasma proteins.

The complete recovery of biologically-active vitamin D obtained by Morgan et al. (1958) was not repeatable in our experiments. Both biological assay and reversed-phase paper chromatography showed that destruction of the vitamin had occurred during the experiment, about threequarters being rendered inactive. These findings were not related to the type of extraction procedure employed; such destruction was found even in the light-petroleum extracts of unfractionated serum. As leaving the vitamin, incubated with serum, on starch overnight had no deleterious effect, it is assumed that this was not the cause of destruction. Also there was no more destruction during electrophoresis. For vitamin A a protection by the serum proteins during electrophoresis was claimed by Erwin et al. (1959). It appears thus that destruction of the vitamin $D$ may have occurred during incubation or during extraction.

Attempts were made to determine by differentialextraction procedures the type and strength of binding. It was hoped that saline would extract the water-soluble material and give a fraction containing protein and tightly bound vitamin $\mathrm{D}$. However, saline extracted about one-half of the vitamin even in the absence of serum. This could be explained by dispersion of the vitamin between starch and saline. More informative results were obtained from the fraction extractable with light petroleum. Although nearly all the vitamin D could be extracted with light petroleum in the absence of serum, in its presence only half was extractable, indicating the presence of a proteinvitamin $D$ complex. The residue could be recovered by ethanol-diethyl ether extraction after splitting the protein bonding with methanol. These results in vitro were confirmed by experiments in vivo with rats (Kodicek, Cruickshank \& Ashby, 1960) and with infants (Kodicek, Cruickshank \& Stapleton, 1960).

If vitamin $D$ were carried by cholesterol (or another lipid) in the lipoprotein fractions, a correlation between its distribution and that of cholesterol would be expected. The distribution of cholesterol in serum (Kunkel \& Slater, 1952a, $b$; Boyd, 1954) does not coincide with that found by us for vitamin $D$, and therefore it appears unlikely that the lipoproteins are concerned with the transport of the vitamin.

\section{SUMMARY}

1. The distribution of ${ }^{14} \mathrm{C}$-labelled vitamin $\mathrm{D}_{2}$ in serum proteins has been studied. The vitamin was incubated in high physiological concentration $(2.5 \mu \mathrm{g} . / \mathrm{ml}$. of serum) in rat serum, and the radioactive material separated by electrophoresis on a starch-supporting medium. Segments of the starch block were eluted with $0.9 \%$ sodium chloride solution, with light petroleum and, after refluxing with methanol, with ethanol-diethyl ether.

2. The radioactive material was found to correspond with the $\alpha_{2}$-globulin and albumin peaks. Although similar amounts were extracted from the two proteins, the $\alpha_{2}$-globulin fraction had a bigger capacity per unit protein than the albumin fraction.

3. In some instances, the remaining radioactive material did not move from the point of application, showing that it was not associated with electrophoretically mobile components. This was probably because the vitamin was present in excess of the binding capacity of the proteins.

4. Biological assay and reversed-phase paper chromatography showed that only about onequarter of the radioactive material recovered was vitamin $D$. It seemed probable that breakdown occurred during incubation or extraction.

5. In the presence of serum, light petroleum extracted only about one-half of the total vitamin D. The residue could be recovered by splitting the protein bonding with boiling methanol.

We wish to thank Dr E. M. Cruickshank for help in the biological assays. One of us (K.J.I.C.) is indebted to the Medical Research Council for a training grant.

\section{REFERENCES}

Bourdillon, R. B., Bruce, H. M., Fischmann, C. \& Webster, T. A. (1931). Spec. Rep. Ser. med. Res. Counc., Lond., no. 158.

Boyd, G. S. (1954). Biochem. J. 58, 680.

Chalk, K. J. I. \& Kodicek, E. (1960). Biochem. J. 74, 22 P.

Crook, E. M. \& El-Marsafy, M. K. (1954). Biochem. J. 57, viii.

Daughady, W. M. (1956). J. clin. Invest. 35, 1434.

Daughady, W. M. (1958). J. clin. Invest. 37, 519.

Erwin, E. S., Varnell, T. R. \& Page, H. M. (1959). Proc. Soc. exp. Biol., N.Y., 100, 373.

Garbers, C. F., Gillman, J. \& Peisach, M. (1958). S. Afr. J. med. Sci. 23, 34.

Garbers, C. F., Gillman, J. \& Peisach, M. (1960). Biochem. $J .75,124$.

Kodicek, E. (1955). Biochem. J. 60, xxv.

Kodicek, E. \& Ashby, D. R. (1954). Biochem. J. 57, xiii. 
Kodicek, E., Cruickshank, E. M. \& Ashby, D. R. (1960). Biochem. J. 76, 15 P.

Kodicek, E., Cruickshank, E. M. \& Stapleton, T. (1960). Abstr. Comm. 5th int. Congr. Nutrition, Washington, p. 57.

Kunkel, H. G. \& Slater, R. J. (1952a). Proc. Soc. exp. Biol., N.Y., 80, 42.

Kunkel, H. G. \& Slater, R. J. (1952b). J. clin. Invest. 31, 677.
Morgan, H. G., Thomas, W. C., Haddock, L. \& Howard, J. E. (1958). Trans. Ass. Amer. Phycns, 71, 93.

Peters, J. R. \& van Slyke, D. D. (1932). Quantitative Clinical Chemistry, Methods, p. 693. London: Baillière, Tindall and Cox.

Thomas, W. C., Morgan, H. G., Connor, T. B., Haddock, L., Bills, C. E. \& Howard, J. E. (1959). J. clin. Invest. 38, 1078.

Biochem. J. (1961) 79, 7

\title{
Carbohydrase and Sulphatase Activities of Porphyra umbilicalis
}

\author{
BY S. PEAT AND D. A. REES* \\ University College of North Wales, Bangor, Caernarvonshire
}

(Received 4 October 1960)

The carbohydrate constituents of the red seaweeds (Rhodophyceae) are characterized by the frequent occurrence of galactose, its derivatives and polymers. The mucilaginous substance of the algae, often present in very large quantities (up to $80 \%$ of the dry weight), is usually a polysaccharide composed of residues of $\mathrm{D}$-galactose and certain of its derivatives, such as galactose sulphate, 3:6anhydrogalactose, 6-O-methylgalactose, as well as L-galactose. Sucrose, a key substance in higher plants, is absent here and its functions are probably taken over by floridoside (Bean \& Hassid, 1955; Bidwell, 1958), which is a glycerol galactoside (2-O $\alpha$-D-galactopyranosylglycerol), commonly found in the red seaweeds. Compounds related to floridoside have also been reported from some members of this class. Such compounds are 1-O- $\alpha$-D-galactopyranosyl-D-glycerol and 1-O- $\alpha$-D-galactopyranosyl-L-glycerol from Porphyra umbilicalis (Lindberg, 1955b; Wickberg, 1958b); 2-O- $\alpha$-D-mannopyranosyl-D-glyceric acid from Polysiphonia lanosa and Ceramium rubrum (Colin \& Augier, 1939; Bouveng, Lindberg \& Wickberg, 1955); $O-\alpha-D-$ galactopyranosyl-(1 $\rightarrow 6)$-O- $\beta$-D-galactopyranosyl$(1 \rightarrow 1)$-D-glycerol from Polysiphonia lanosa and Corallina officinalis (Wickberg, 1958a); and $O-\alpha-\mathrm{D}$ mannopyranosyl-(1 $\rightarrow 3)$-O- $\alpha$-D-galactopyranosyl$(1 \rightarrow 2)$-glycerol from Furcellaria fastigiata (Lindberg, 1955a).

A common reserve polyseccharide of the red seaweeds is floridean starch, which contains no amylose component and is a polysaccharide of the glycogen-amylopectin type (Fleming, Hirst \& Manners, 1956; Peat, Turvey \& Evans, 1959).

The synthesis and transformation of carbohydrates in these seaweeds has as yet received little

* Present address: Department of Chemistry, The University, Edinburgh 9. attention. Some of the enzyme activities present in extracts of Rhodymenia palmata and Iridophycus flaccidum have been described (Duncan, Manners \& Ross, 1956; Bean \& Hassid, 1956), and the fate of ${ }^{14} \mathrm{CO}_{2}$ after incorporation into certain species has also been studied (Bean \& Hassid, 1955; Bidwell, 1958).

Seaweeds of the genus Porphyra belong to this class. Porphyra umbilicalis grows on the Welsh coast and is collected and marketed in quantity for human consumption. It is a relatively primitive organism, belonging to the subclass Bangioideae (Fritsch, 1945). The carbohydrates present have been investigated by a number of workers. The major polysaccharide (which sometimes represents over $30 \%$ of the dry weight), to which the name of porphyran is given, contains residues of $\mathrm{D}$-galactose, L-galactose, 3:6-anhydro-L-galactose, 6-O-methyl$D$-galactose and galactose ester sulphate (Turvey \& Rees, 1958), much of the ester sulphate being carried at the 6-position of L-galactose residues (Turvey \& Rees, 1961). A similar polysaccharide has been isolated from Porphyra capensis (Nunn \& von Holdt, 1957). The presence of floridean starch has been demonstrated in Porphyra umbilicalis (Turvey \& Rees, 1958), and the principal lowmolecular-weight carbohydrates have been shown to be floridoside and isofloridoside (Lindberg, $1955 b$ ). The latter is stated to be a mixture of 1-O- $\alpha$-D-galactopyranosyl-D-glycerol and 1-O- $\alpha-\mathrm{D}-$ galactopyranosyl-L-glycerol (Wickberg, 1958b). Porphyra is unusual in the nature of the skeletal polysaccharide of the cell wall, which is not cellulose but a $\beta$-1:4-linked polymannose (Jones, 1950; Cronshaw, Myers \& Preston, 1958).

The purpose of this paper is to describe the results of a preliminary survey of the enzymes present in extracts of Porphyra umbilicalis, particular 